Margareta, Safnil, Irwan Koto, A Need analysis on...

\title{
A NEED ANALYSIS ON ICT-BASED ENGLISH MATERIAL FOR TEACHING AND LEARNING OF READING FOR HIGH SCHOOL STUDENTS IN SOUTH BENGKULU
}

\author{
MARGARETA \\ SAFNIL \\ IRWAN KOTO
}

UNIVERSITY OF BENGKULU

\begin{abstract}
This research was aimed to find out ICT media are preferred by high school students in South Bengkulu in learning reading and to describe the reading materials should be used with ICT media. The research design was mixed method quantitative and qualitative with the subjects of this research were 302 high school students and 11 English teachers in South Bengkulu. The instruments of this research were questionairre and open-ended interview. The findings of the research revealed that (1) online ICT media was prefered by high school students in South Bengkulu in learning reading and (2) kinds of text became the reading material that should be used with ICT media. To suggest, a broader field test still needed to be done to achieve a better result and other researchers who are interested in the incorporation of ICT in learning teaching are suggested to conduct further investigation which possibly deals with other language skills.
\end{abstract}

Key Words: Need Analysis, ICT-Based English Material, Teaching and Learning of Reading

\section{INTRODUCTION}

In Indonesia, learning using ICT media has been developing, especially for school which able to provide such media (Sutrisno, 2012). He said the leading cause of the use of ICT media in many schools because practical value, economic value and easy in using. All the reasons make learning more interesting, easy and can be implemented wherever and whenever.

Related to that phenomenon, ICT is also become source of teaching and learning especially in reading. The use of ICT's for reading has many advantages, as Melor et al (2013) had identified both advantages and disadvantages of using ICT in teaching ESL reading and writing, The findings of the study revealed that attracting students' attention, facilitating students' learning process, helping to improve students' vocabulary knowledge and promoting meaningful learning were regarded as the most important advantages of using ICT in teaching ESL reading and writing. Another related study on the use of ICT in the teaching of reading specifically, Yuksel\&Tanriveddi (2009) explored the effects of watching captioned movie clip on vocabulary development of EFL learners, when the findings of this study are interpreted, it can be argued that viewing the movie clip has helped the participants of the study develop their vocabulary knowledge, and this would facilitate the reading process.

In the history of English instruction in Secondary School in Indonesia, reading ability was considered very important. In the English curriculum, the four language skills or competencies (listening, speaking, reading and writing) have equal position. However, special consideration is still given to the reading competency as the 
competency which is assessed in the 'UjianNasional' (National Assessment).

Reading, one of language skills, should be mastered well by the students because reading is an essential factor that influences one's activity in communication. Reading is regarded as a decoding skill, which is, interpreting codes into ideas. People consider reading as an important activity, so that people usually say that reading is the window of the world. By reading, people can get the information widely without going anywhere

Considering the important of reading for students in Senior high school, the researcher observed the way of English teachers teach in the classroom in some schools in Bengkulu Selatan. The teacher there did not integrated ICT in implementing their reading instructions even though there was possibility to do so. They only used the textbook which is officially recommended. The book merely crammed with reading text followed with series of comprehension questions. The reading materials were not adequate to achieve the competencies stated in the new curriculum, curriculum 2013, which is integrated the ICT in teaching and learning process. Teaching and learning reading with CALL and ICT could make the learning process more exciting and interesting.

Another problem is that the time allocated for teaching and learning in the

\section{METHODOLOGY}

This study employed the mixed method design which is the combination of qualitative and quantitative approach to collect and analyze data. The participants in this research were students grade $X$ and the English teachers in 3 state senior High Schools. The researcher defined the participant that has certain qualities and characteristics Sugiyono (2010) stated that the participants are the generalization region consisting of objects or subjects classroom is not sufficient. According to Curriculum 2013, the allocated time for English at SMA as a general program is only two hours in a week. Within these teaching and learning hours, the teacher got the difficulties to deliver the basic competencies that students must be achieved, meanwhile for the students; it is very limited time for them to acquire the language. Moreover, most of the schools in South Bengkulu have the large number of students in a classroom. The limited time and the large number of students in classroom may not enough to overcome students' way in learning. To overcome this situation, the students need to intensify learning outside the classroom. And ICT could be used in this situation.

Alberth (2013) said that the using of ICT can overcome almost the lack of teaching and learning English such as lack of exposure the language, less exercises, and lack of learning sources. But, eventhough it is proved effective for teaching and learning English, it is important to conduct need analysis in order to response this changing situation.

Due to the situation above, this can be carried out by researcher and educator involving staff and students. One of the purposes of need analysis is to know what needs should be fulfilled in matching with the needs of present situation. Need analysis needs to conduct in knowing the students' wants.

that have certain qualities and characteristics. Based on the tables above, the total participants were 302 Students and 11 English teachers. The participants were chosen by considering the number and the quality of the school. It was required to keep the variety of the data. Some instruments were applied to obtain the data in this research. The researcher collected them through three different techniques, namely; questionnaire, 
interview, and documentation. Since it was a mixed method research, there were two Types of data that were analyzed by the researcher. This design first begins with the collection and analysis of quantitative data and followed by the collection and analysis of qualitative data. In the explanatory design, the researcher recognizes particular quantitative findings that need further explanation. To keep the validity of the data, the researcher decided to use expert judgment and triangulation method of three instruments used; questionnaire, interview, and documentation

\section{RESULT AND DISCUSSION}

After conducting the need survey, the result of the questionnaire was analyzed by the researcher. This part presents the data obtained in the needs

analysis. There were two kind of ICT used in the questionairre, namely offline and online ICT used. The detail findings will be explained as follow:

\section{ICT media preferred by senior high school students}

a. Questionnaire

\section{1) Offline ICT media used preferred by high school students}

There were seven questions about students' preferring of offline ICT used, namely; the use of computer or laptop, the place used the ICT media, the frequency of using ICT media, the activities when using ICT media, the attitude of using ICT media, the attitude of using ICT media in reading activity, the frequency of using ICT media in reading. The findings of seven items of offline ICT used were displayed in the following table.

Table 1. The finding of offline ICT usage

\begin{tabular}{|c|c|c|c|}
\hline Aspects & $\begin{array}{l}\text { Categories of } \\
\text { response }\end{array}$ & $\begin{array}{c}\text { Number of } \\
\text { students }\end{array}$ & $\begin{array}{c}\text { Percentage } \\
(\%)\end{array}$ \\
\hline \multirow{2}{*}{$\begin{array}{l}\text { Using computer or } \\
\text { laptop }\end{array}$} & like & 256 & 84,76 \\
\hline & Dislike & 46 & 15,24 \\
\hline \multirow{3}{*}{$\begin{array}{l}\text { The place of using } \\
\text { computer or laptop }\end{array}$} & at home & 168 & 55,63 \\
\hline & at school & 110 & 36,42 \\
\hline & Otherplace & 24 & 7,95 \\
\hline \multirow{4}{*}{$\begin{array}{l}\text { The frequency } \\
\text { ofusing computer or } \\
\text { laptop }\end{array}$} & $\begin{array}{c}\text { very often } \\
\text { (> } 4 \text { hours/day) }\end{array}$ & 123 & 40,73 \\
\hline & $\begin{array}{c}\text { Often } \\
\text { (2-4 hours /day) }\end{array}$ & 89 & 29,47 \\
\hline & $\begin{array}{l}\text { Often enough } \\
\text { (1 hour/day) }\end{array}$ & 67 & 22,19 \\
\hline & $\begin{array}{c}\text { Rarely } \\
\text { (a half hour/day) }\end{array}$ & 23 & 7,62 \\
\hline \multirow{3}{*}{$\begin{array}{l}\text { Activity done while } \\
\text { using computer or } \\
\text { laptop }\end{array}$} & Playing game & 98 & 32,45 \\
\hline & $\begin{array}{l}\text { Learning/doing } \\
\text { assignment }\end{array}$ & 123 & 40,73 \\
\hline & $\begin{array}{l}\text { Other } \\
\text { activities... }\end{array}$ & 81 & 26,82 \\
\hline \multirow{2}{*}{$\begin{array}{l}\text { Motivation in using } \\
\text { ICT media in } \\
\text { learning English }\end{array}$} & Motivation & 167 & 55,30 \\
\hline & No Motivation & 135 & 44,70 \\
\hline
\end{tabular}




\begin{tabular}{|c|c|c|c|}
\hline $\begin{array}{l}\text { especially in reading } \\
\text { activity }\end{array}$ & & & \\
\hline The important of & Important & 234 & 77,48 \\
\hline $\begin{array}{l}\text { using ICI media in } \\
\text { reading activity }\end{array}$ & Not Important & 68 & 22,52 \\
\hline Theextent important & Very Important & 215 & 28,81 \\
\hline $\begin{array}{l}\text { media in reading } \\
\text { activity }\end{array}$ & Important & 87 & 71,19 \\
\hline
\end{tabular}

Table 1 shows the number of students who likes to use computer or laptop was about 256 students or $84,76 \%$ of the total students and 46 students or $15,24 \%$ of students dislike to use computer or laptop. It means that almost a half of total students like to use computer or laptop. Based on table above, 55,63\% (168 students) usually use computer or laptop at home, 36,42\%(110 students) use computer at school, and 7,95\%(24 students) usually use computer or laptop at other places, such as at wifi area, at park, and at their car. However mostly students use computer or laptop at home. The third question is about the students frequency of using ICT media. The categories were divided into four; very often, often, often enough, and rarely. Moreover, the finding revealed that the students use computer or laptop very often. It was proven by the students' answer which was about $40,73 \%$ or 123 students answered very often in using computer or laptop. Then, 89 $(29,47 \%)$ of students answered often, 67 $(22,19 \%)$ of students answered often enough, and the rest 7,62\% (23 students) answered rarely.

Table 1 also shows the students' activities when using ICT media, the researcher found that 123 or $40,73 \%$ of students often learn or do assignment when using computer or laptop. Then, 98 or $32,45 \%$ of students often play game while using computer or laptop. For the rest, $81(26,82 \%)$ of students answered other activites, the activities are editing photo, reading comic, reading story, and programming. However, mostly students answered learning or doing assignment as the activity that the students often do when using computer or laptop. The Table also showed that more than half of studentss are motivated use ICT media in learning English especially in reading activity. The finding revealed that $55,30 \% \quad(167$ students) answered yes and 135 (44,70\%) of students answered no. The sixth question was about the attitude of using ICT media in reading activity. There were 234 students or $77,48 \%$ of the students answered yes, it means that the use ICT media is important in reading activity, meanwhile $68(22,52 \%)$ of students answered no.

Related to the previous question, the rest question for offline ICT used was about how important the using ICT media in reading activity. Regarding to the finding, $215(71,19 \%)$ students answered very important and $87(28,81 \%)$ of students answered important to use ICT media in reading activity. Moreover, the finding revealed that the using ICT media in reading activity was very important, not only important among senior high school students in Bengkulu Selatan.

\section{2) Online ICT media used preferred by high school students}

There were eight questions related to students' preferring of online ICT used, namely, the use of internet, the place of using internet, ICT media in accessing internet, activities in accessing internet, the frequency in accessing reading material, the reading material which often accessed in internet, the reading activity in 
accessing internet, and the application or activity using internet.

media which help the students in reading

Table 2. The finding of online ICT usage

\begin{tabular}{|c|c|c|c|}
\hline Aspects & $\begin{array}{l}\text { Categories of } \\
\text { response }\end{array}$ & $\begin{array}{l}\text { Number of } \\
\text { students }\end{array}$ & $\begin{array}{l}\text { Percentage } \\
(\%)\end{array}$ \\
\hline \multirow[b]{2}{*}{ The use of internet } & Often & 285 & 94,37 \\
\hline & Never & 17 & 5,63 \\
\hline \multirow{3}{*}{$\begin{array}{l}\text { The place of using } \\
\text { internet }\end{array}$} & In home & 177 & 58,61 \\
\hline & In school & 69 & 22,85 \\
\hline & Other place.... & 56 & 18,54 \\
\hline \multirow[t]{3}{*}{$\begin{array}{l}\text { The media used to access } \\
\text { the internet }\end{array}$} & $\begin{array}{c}\text { Computer/lapto } \\
\mathrm{p}\end{array}$ & 89 & 29,47 \\
\hline & Tablet & 43 & 14,24 \\
\hline & Handphone & 170 & 56,29 \\
\hline \multirow{3}{*}{$\begin{array}{l}\text { The activities done when } \\
\text { accessing the internet }\end{array}$} & Browsing & 121 & 40,07 \\
\hline & Playing game & 56 & 18,54 \\
\hline & Social media & 125 & 41,39 \\
\hline \multirow{4}{*}{$\begin{array}{l}\text { The frequency of } \\
\text { accessing reading } \\
\text { material through internet }\end{array}$} & $\begin{array}{c}\text { very often } \\
\text { (> } 4 \text { hours/day) }\end{array}$ & 25 & 8,28 \\
\hline & $\begin{array}{c}\text { Often } \\
\text { (2-4 hours /day) }\end{array}$ & 70 & 23,18 \\
\hline & $\begin{array}{l}\text { Often enough } \\
\text { ( } 1 \text { hour/day) }\end{array}$ & 164 & 54,30 \\
\hline & $\begin{array}{c}\text { Rarely } \\
\text { ( a halfhour/day) }\end{array}$ & 43 & 14,24 \\
\hline
\end{tabular}

Table 2 shows the number of students who often use internet was about 285 students $(94,37 \%)$ of the students and 17 students or $5,63 \%$ of students did not often to use internet. It means that almost all of the total students often use internet. Based on table above, 58,61\% (177students) often use internet at home, $22,85 \%$ (69 students) often use internet at school, and $18,54 \%$ or 56 students often use internet at other places, such as at wifi area, at internet camp "warnet", and at cafetaria. However a half of total students often use internet at home. Furthermore, there were $56,29 \%$ (170 students) use handphone as media to access internet. Then 89 or $29,47 \%$ students use computer or laptop and $43(14,24 \%)$ students use tablet to access internet. However, no other media used by the students to access the internet, but those three medias; computer or laptop, tablet, and handphone.

When accessing the internet, almost half of the total students often access social media. It was proven by the finding that $125(41,39 \%)$ of students answered social media as the activity do when accessing internet. After that, there were $40,07 \%$ (121 students) answered browsing activity, then $56 \quad(18,54 \%)$ 
sudents answered playing game as the activity often done while accessing internet. However, no student mentioned other addition activity often done while accessing the internet .

The next question was about the students frequency in accessing reading material. The categories were divided into four; very often, often, often enough, and rarely. Moreover, the finding revealed that the students access reading material often enough. It was proven by the students' answer which was about 54,30\% (164 students) answered often enough in accessing reading material through internet . Then, $70(23,18 \%)$ of students answered often, $43(14,24 \%)$ of students answered rarely, and the rest $8,28 \%$ or 25 students answered very often.

Based on the findings, both offline and online ICT was important and helpful as teaching media especially in reading activity. Regarding to the questionnaire analysis result, there were some conclusions that can be identified; (1) the students like to use computer or laptop, (2)

\section{b. Interview}

The need analysis not only used questionairre, but also open-ended interview which was done to the English teachers. There were 11 English teachers who become the respondents of this research. The interview was done after giving the questionaire. There were 9 questions which was interviewed to the respondents using English language.

However, the respondents' answers indicated that ICT was very helpful in reading activity. It was not only as teaching material but also as teaching

\section{c. Documentation}

The documentation was used to find out the data about the syllabus that was taught in senior high school level. the students often use computer or laptop at home, (3) the students use computer or laptop very often, (4) the students often learn or do assignment while using computer or laptop, (5) the students are motivated use ICT media in learning English especially in reading activity, (6) the use ICT media is important in reading activity, (7) the using ICT media in reading activity was very important, not only important, (8) almost all of the total students often use internet, (9) a half of total students often use internet at home, (10) students use handphone as media to access internet, (11) When accessing the internet, almost half of the total students often access social media, (12) that the students access reading material often enough, (13) the students often access any Types of texts as reading materials through internet, (14) more than half of students often do translating as reading activity using internet and ICT media, (15) The application or media which help the students in reading activity through internet was online dictionairy.

There were five questions which related to the research question 1.For the third question "do the teachers often use computer, laptop, or internet in teaching process?", there were eight from eleven teachers who answered yes, and for the rest, they answered no.

media. The use of offline and online ICT has its own role toward students' motivation, creativity, and achievement in reading activity.

Based on the syllabus, mostly the teachers used ICT media in teaching reading for example using power point in teaching. 


\section{Reading material to be used with ICT Media \\ a. Questionnaire}

The result of the questionnaire will be showed as follow:

Table 4.3. The Finding of Reading Materials

\begin{tabular}{|c|c|c|c|}
\hline Aspects & $\begin{array}{l}\text { Categories of } \\
\text { response }\end{array}$ & $\begin{array}{l}\text { Number of } \\
\text { students }\end{array}$ & $\begin{array}{l}\text { Percentage } \\
(\%)\end{array}$ \\
\hline \multirow{3}{*}{$\begin{array}{l}\text { The reading materials } \\
\text { often accessed through } \\
\text { the internet }\end{array}$} & News/article & 44 & 14,57 \\
\hline & Fiction story & 98 & 32,45 \\
\hline & $\begin{array}{l}\text { Any Types of } \\
\text { texts }\end{array}$ & 160 & 52,98 \\
\hline \multirow{2}{*}{$\begin{array}{l}\text { The reading activities } \\
\text { are done by using } \\
\text { internet and ICT } \\
\text { media }\end{array}$} & Translating & 189 & 62,58 \\
\hline & Browsing & 113 & 37,42 \\
\hline \multirow{2}{*}{$\begin{array}{l}\text { The application in } \\
\text { internet that often } \\
\text { accessed to help } \\
\text { students in reading } \\
\text { activities }\end{array}$} & Browsing internet & 92 & 30,46 \\
\hline & $\begin{array}{l}\text { Using online } \\
\text { dictionary }\end{array}$ & 210 & 69,54 \\
\hline
\end{tabular}

Table 4.3.Shows that there were three aspects of questionnaire relating to the reading materials that answered the second research question of this research.Regarding to Table 4.3 , the students often access any Types of texts as reading materials through internet. The finding revealed that 52,98\% (160 students) often access any Types of texts, 98 or $32,45 \%$ students access fiction story, then $14,57 \%$ (44 students) access news/articles as reading materials through internet. However, none of students access another reading materials except those three. Table 4.3 also showed that more than half of students often do translating as reading activity using internet and ICT media. It was revealed by the finding which was

\section{b. Interview}

For the question; what Types of reading activity that often taught to the students?, the respondents' answers were various. One of the respondent answered: about $62,58 \%$ or 189 students answered translating as the activity done, while for the rest there were 113 or $37,42 \%$ of students do browsing as reading activity and none answered other activity.

The application or media which help the students in reading activity through internet was online dictionairy. The finding revealed that $69,54 \%$ (210 students) answered online dictionairy as the media often used to help their reading activity. While, there were 92 or $30,46 \%$ of students answered browsing internet to find the source of reading materials as a media to help reading activities. For the rest, no student mentioned another application or media used.

\section{Respondent 1:}

"In reading activity I often taught about learning some genre of text, for example descriptive, narrative, etc. Then 
the students need to analyze what the text talking about, the main idea, the purpose of the text, and mostly activity done to help the students in facing UN. So I keep teaching Types of genre text"

While, for the second question; what Types of the obstacle that the students need to solve in reading activity?, one of the respondent commented:

\section{Respondent 2:}

"There were some Types of obstacle that must be solved by the students, such as identfying main idea, making inference, and understanding difficult vocabulary. These Types of obstacle can not be solved effectively among the students. The teacher and students need to solve this obstacle together"

The next question asked about "is there any special program or application

\section{c. Documentation Findings}

The documentation was used to find out the data about the syllabus, lesson plan, and teaching reading materal that was taught in senior high school level. Based on the documentation, the researcher found that there were several Types of text that was used in reading

\section{Discussion}

Other study also showed that using technology in teaching improves communication and teamwork among students. Martin (2003), a reading specialist at Grace Park Elementary School who serves as a technical support teacher, trained the teaching staff in the use of software and motivated students to use technology equipment in reading class. Martin focused on the benefits of using computers to enhance reading skills. As a reading specialist, the researcher which helped the students in reading activity? Respondent 10 answered the question:

Respondent 10:
"Actually there is no special
program or application, but
the teacher often uses such
kind of video or film in
teaching reading. Maybe
power point can be said as
program that often used in
teaching reading. The
teacher often uses Power
point as media to display
kind of picture which
related to the kind of text
taught.

For the rest question is about students' interest in using offline or online ICT in reading class. All of the respondents answered that the students showed their interest toward the use of ICT media in teaching reading.

class, namely; short functional text, recount, narrative, and procedure text, functional text. Moreover, this finding supported the findings of questionaire and interview which revealed that types of text became the reading material that should be used with ICT media.

investigated some technology means to motivate students before, during, and after the reading class. The researcher used observation as the research instrument, observing the students' interactive use of a suitable reading website. The findings showed that students loved and did well with the website reading, communicated with each other, and that the laptops motivated students to work cooperatively. These studies have proved the advantages of teaching with technology along with 
textbooks and other traditional approaches (Martin, 2003).

In another study to improve reading speed and comprehension of ESL students using computers, Culver (1991) implemented a computer reading program to determine the exit and entrance scores of ESL college students and to find out if their reading speed and comprehension would improve. The results showed some improvements for the majority of students in the target group with an overall increase of 3.9 grade level in reading rate. The results show important information about the effect of increasing reading speed on student comprehension as a result of employing computers. It was concluded that the computer was a good tool for improving students' reading rate despite the fact that increased speed did not lead to increased levels of comprehension for some students.

In Indonesia, the recent research conducted by Arimbawa et al (2013), it was about developing ICT-based reading materials for grade eight students of Junior High School at SMPN 1 Kubutambahan which met the criteria of good reading materials and investigating whether the ICT-based reading materials were able to improve the students' reading competency. This finding supported the present research findings that online ICT usage was useful to improve the students' motivation and achievement in reading comprehension.

Furthermore, the finding of this research also confirmed some theories and ideas from the expert. The finding accepted the theory from Kenworthy (2004) who explained there are many Internet Web sites prepared solely to enhance the reading abilities of English language learners. There are also a huge number of resources available in the form of newspaper, magazines, journal, electronic libraries, electronic dictionaries, encyclopedias, and newsletters. Browsing this resources and sites will obviously enhance the learner's vocabulary and reading ability. Moreover, another modern way for improving the vocabulary of the learner focuses on the utilization of electronic dictionaries designed especially for English language learners. These dictionaries have several built- in and tools that are not provided in book dictionaries (Constantinescu. 2007).

As Nuttall (1996: 172) states that the wide variety of different types of text means that it is easier to find something that will interest the learner and may even encourage further reading or reading for pleasure. The more learners reading,the better readers they will become. In addition, if the text interests the learners, they willfeel more confident and more secure when reading the texts. It means they not only improve their language level but also confidence. It was similar to the respondents' answers in finding of interview of this research. The students became more anthusiast and confidance in learning activity.

Knapp and Watkins ( 2005: 17) said that the aim of genre, text and grammar approach is to provide students with the ability to use the codes of writing (the genre and grammar ) effectively and efficiently. Without these codes the process of writing can be frustrating and unproductive process. Genre or text type has been taught in all senior high schools, it is also required the students to differenciate and understand each text type.

Moreover, a group of ICT researchers claim that using ICT improves education and provides more teaching and learning supports for the teachers and learners (see Westera\&Sloep, 2001; Young, 2003; Salehi\&Salehi, 2012; Yunus, Salehi\&Chenzi, 2012). There is no doubt that using ICT in education improves teachers' instructional process and facilitates students' learning process. A great number of studies have shown the advantages of using ICT in ESL teaching and learning. In line with this research findings, the use of ICT both offline and online affects the learning process. It can 
positively improve the students' interest to

\section{CONCLUSION}

Based on research findings, it can be concluded that (1) online ICT media rather than offline ICT media were prefered by high school students in South Bengkulu in learning reading. Both online ICT and Offline ICT media covered such

\section{REFERENCE}

Aebersold, Jo Ann and Feld, Mary Lee (1997) From Reader to Reading Teacher.Cambridge: cambridge University Press

Alberth (2013) 'Technology-Enhanced Teaching: A Revolutionary Approach to Teaching English as a Foreign Language' dalam TEFLIN Journal, Vol. 24, No. 1, pp: 1-13

AlKahtani, S. (1999).Teaching ESL reading usingcomputers.The Internet TESL Journal, 5(11).Retrieved from http://iteslj.org/Techniques/AlKaht ani-ComputerReading

Arimbawa, I Nyoman (2013).e-Journal Program

PascasarjanaUniversitasPendidikan GaneshaProgram

StudiPendidikanBahasaInggris (Volume 1 Tahun 2013) :Singaraja

Berardo. (1996) Authenticity in the language classroom Applied Linguistics 6/1 pp60-70

Bryman, Alan (2006)Social Research Method 2nd ed. Oxford. Univ Press.

Brown, H. Douglas. 2001. Teaching by Principles: An Interactive Approach toLanguage Pedagogy. New York: Pearson Education.

Constantinescu, A. I. (2007). Using technology to assist in vocabulary acquisition and reading comprehension. The Internet TESL Journal, 13(2). Retrieved from learn reading.

as; laptop/computer, smartphone, and tablet. (2) Reading material to be used with ICT media covered some types of reading materials ,namely; short functional text, recount, narrative, and procedure text.

http://iteslj.org/Articles/Constantin escu-Vocabulary.html

Creswell, John W. (2014).Research design (qualitative, quantitative, mixed method approaches).University of nebrasca- Lincoln.

America.UnitedState

Culver,SJ (1991) Early Cambrian from West Africa. Science 254

Davies, Florence. (1995)Introducing Reading. England: Penguin Book

Desti. (2008). Teaching reading using POSSE strategy. Unpublished thesis

Dit.PSMA. (2010).JuknisPengembanganBahan Ajar SMA. Jakarta: kementerianPendidikanNasional.

Doff, A. (1997)Trainers Handbook: Teach English A training course for teachers.

Dudley-Evans, T. \& St. John, M. (1998).Developments in ESP: A multi-disciplinary

Gay\& Aerasia. (2000). Educational Research: Competencies for Analysis and Application.Third edition. New York: Macmillan Publishing Company.

Grabe, W., \&Stoller, F. L. (2002). Teaching and researching reading. Harlow: Pearson Education. 
Grellet, Frncoise. 1998. Developing Reading Skills: A Practical Guide to ReadingComprehension Exercises. Cambridge: Cambridge University Press

Hornby, AS. 1987. Oxford Advance Learner's Dictionary of Current English.Oxford: Oxford University Press.

Hutchinson, T. and Waters, A. (1987). English for specific purposes: A learning-centered approach. Cambridge: Cambridge University Press

Jordan W. J., Lara J., McPartland J. M. (1994). Exploring the complexity of early dropout causal structures.Baltimore, MD: Center for Research on Effective Schooling for Disadvantaged Students, The John Hopkins University. Google $\underline{\text { Scholar }}$

Kemendikbud ( 2016). Silabus Mata Pelajaran SMA/MA/SMK/MAK

Kenworthy, R. C. (2004).Developing writing skills in a foreign language via the internet.The Internet TESL Journal, 10(10). Retrieved fromhttp://iteslj.org/ Techniques/KenworthWritingSkills.html

Kim, H. S. (2014). Emerging mobile apps to improve English listening skill.MultimediaAssistedLanguageLearning, 16(2), 11-30.

Longman. (1998). Teaching reading to english language learners insights from linguistics. New York: The Divison of Guiford Publications, Inc.

Martin., (2003). Longman dictionary of language teaching and applied linguistics, third ed. Pearson Education, London.
Melor at al. (2013). Using ICT in teaching English. TEFLIN Journal, Vol. 25, No. 1, pp: 123-138.

NomasBasma Basher. (2013) The Impact of Using Technology in Teaching English as

SecondLanguageinEnglish

Language and Literature Studies; Vol. 3, No. 1; 2013ISSN 19254768 E-ISSN 1925-4776 Baghdad: Canadian Center of Science and Education

Nuttall, C.( 1996)Teaching Reading Skills in a foreign language. Oxford:

Heinemann

Nunan, D. (1988b). The learner centered curriculum. Cambridge: Cambridge University Press.

Nunan, D. (1988a). Syllabus design: London: Oxford University Press.

Nunan, D.( 2003)Practical English Language Teaching. Singapore: McGraw Hill.

Patton, M. Q (1999). Grand Canyon Cekbration:AFather-SonJourny ofDiscovery. Amherst,NY: Prometheus Books.

Priharudi, ZanuRahmat. (2013). The Application of Peer Discussion in The Classroom to Improve Reading Comprehension of The XI Grade Students at SMA N 1 Salaman.Thesis. Yogyakarta: UNY Press

Richards, J. C. \& Rodgers, T. S. (1986).Approaches and methods in language teaching: Adescription and analysis. Cambridge: Cambridge Teaching Library.

Robinson, P.C. (1991). ESP today: A practitioner's guide. New York: Prentice Hall International. 
Richard, J.C. (2001) Curriculum Development in Language Teaching. Cambridge: Cambridge University Press

Robinson, (1991). Ecology, morphology and taxonomy of the Lake Malawy Oreochromis (Nyasalapia)species flock. Ann. Mus. R. Afr. Centr., Sc. Zool., 262:23-28.

Santoso. (2015)Progress and challanges in Platelet Serology. Published Journal

Safitri, Isnaini N. (2012)Improving Grade XI Students' Reading Comprehension by Using Collaborative Strategic Reading (CSR) in Sman 1 Sewon in The Academic Year of 2011/2012. Thesis. Yogyakarta: English Education Department, FBS, UNY.

Salehi, H., \& Salehi, Z. (2012). Integration of ICT in language teaching: Challenges and barriers. Proceedings of the 3rd

. Alfabeta
International Conference on eEducation, e-Business, eManagement and e-Learning (IC4E, 2012). IPEDR, 27, 215-219.

Seedhouse, P. (1994). Using newspapers on CD-ROM as a resource.TESLEJ, 1(2). Retrieved from http://www.tesl org/word press /issues/ volume1 /ej02 /ej02a3/

Seyler, Dorothy U. (2004). The readingcontext: developing college reading skills. New York :Pearson Education, Inc.

Silver, B. F. (1997).Verbal Behavior. New York: Appleton-Century-Crofts.

Soriano, F. (1995). Conducting Needs Assessments: A Multidisciplinary Approach. Sage Human Services Guide \#68. Sage Publications: Thousand Oaks, CA.

Practical Guide. Sage Publications: Thousand Oaks, CA.

Sugiyono. (2010). MetodePenelitianPendidikan: PendekatanKuantitatif, Kualitatif, dan $\quad R \& D . \quad$ Bandung 